\title{
Work Health and Safety in Small Business-A Pilot Study in the Australian Construction Industry
}

\author{
Raed Eldejany ${ }^{1}$ \\ ${ }^{1}$ All Facility Services, Revesby, New South Wales, Australia \\ Correspondence: Raed Eldejany, All Facility Services, Revesby, New South Wales, Australia.
}

Received: June 16, 2018

Accepted: July 2, 2018

Online Published: July 10, 2018

doi:10.5430/ijba.v9n4p103

URL: https://doi.org/10.5430/ijba.v9n4p103

\begin{abstract}
Work accidents impacts negatively on the physical, mental and social welfare of employees, increase cost of production, and make firms less competitive. The construction industry in Australia consists of $96 \%$ small business and has the fifth largest incident rates of serious injury of all industries. Nevertheless, recent statistics by the Australian Bureau of Statistics show noticeable improvement in safety performance within the construction industry compared to previous years.

This descriptive pilot study attempts to verify small business contribution to this recent improvement. Ten owner managers are surveyed in order to examine their commitment to work health and safety using a 34 self-completion questionnaire. The findings show that small business owners in the construction industry take a positive approach toward work health and safety in their work environment.

This study represents only a snapshot of the reality of small construction business commitment to work health and safety in Australia and can't be generalised to a wider population, therefore further research with larger samples is required to confirm the findings of this study.
\end{abstract}

Keywords: small business, work health and safety, construction, owner manager

\section{Introduction}

Safe Work Australia (SWA) (2015) ranks the construction industry as having the fifth largest incident rates of serious injury of all industries. In 2011-12 the construction industry record an incident rate of 18.7 claims per 1000 employees, which compares to the national all industries rate of 12.2 serious claims per 1000 employees. Small business contributes significantly to this statistics as it constitutes $96 \%$ of the total number of business that operate within the construction industry (Australia Parliament House (APH), 2016). This situation according to Koper, Moller and Zwetsloot (2009) impacts negatively on the physical, mental and social wellbeing of employees, increase cost of production, and make firms less competitive.

However, recent data published by SWA (2016), show that the Australian average incident rate for the construction industry has decreased by $11 \%$ between $2011-12$ and 2014-15 and worker fatalities is down by $19 \%$ compared to worker fatalities in the previous ten years. The fact that small business still constitutes around $96 \%$ of the total number of business that operate within construction industry implies that small business maybe playing a crucial role in improving these statistics.

This pilot study attempts to verify small business contribution to the reduction in work injury incident rates in the construction industry. A sample of ten small construction businesses, employing less than 19 employees, is surveyed in order to examine their owners' understanding and commitment to the implementation of work health and safety (WHS). This study will add to the little available literature in the field of WHS in small construction business (Hasle, Limborg, Kallehave, Klitgaard, \& Andersen, 2011; Smallman, 2001) and improve our knowledge of owner managers' understanding and commitment to WHS.

\section{Literature}

\subsection{Small Business in the Construction Industry}

In recent years managing risks has become an essential component of organisational operation because it cuts accident rates and improve business productivity, economic and financial results (O'Toole, 2002). According to the 
Australian Bureau of Statistics ABS (2017), as of 30 June 2016, the number of actively trading businesses in Australia is $2,171,544,16 \%(347,447)$ of which operate in the construction industry, $96 \%$ of the 347,447 active construction businesses are small business that employ less than 19 employees (APH, 2016). According to APH (2015), as of 2013-14 small business in the construction industry contribute \$50 billion to GDP which highlights the importance of managing risks in small construction businesses.

\subsection{Reasons for High Rate Accidents in Small Construction Business}

Existing literature in WHS shows that small business owner managers contribute to the high rate of accidents in the construction industry. First, owner managers comprehend risk in terms of issues internal to their workers, such as lack of knowledge and attention (Holmes, Lingard, Yesilyurt, \& DeMunk, 1999) and conceptualize risk control as an obligation of the individual rather than the business (Lingard \& Holmes, 2001). Second, owner managers don't invest in developing and implementing safety management systems that consist of policies, systems, strategies, and complying standard procedures to ensure the health and safety of workers (Muniz, Peon, \& Ordas, 2009). This shows lack of commitment to WHS and undermines the key role it plays in positively influencing workers' understanding of their rights, responsibilities and obligations under WHS laws (Cohen, 1977; O'Toole, 2002). These issues pose difficulties for the prevention of work accidents, injuries and diseases therefore contribute to high occupational injury rates in small construction business (McVittie, Banikin, \& Brocklebank, 1997).

\subsection{Safety Management System}

A safety management system is a planned process integrated within the business operation designed to: 1) ensure that every precaution is taken to reduce or eliminate the likelihood of an incident in the workplace, 2) ensure compliance with the relevant legislations, 3) create awareness, understanding, motivation and commitment among all business employees (Muniz et al., 2009), 4) reduce accidents, improve business productivity, economic and financial results (O’Toole, 2002). However, its implementation success depends on management's commitment (Zohar, 1980).

\subsection{Components of a Safety Management System}

According to Muniz et al. (2009) a safety management system consists of the following components: safety policies, incentives, training and development, communication, planning, and controls.

\subsubsection{Safety Policy}

A safety policy shows that a business is committed to the safety of its employees, contractors, clients, and public. It includes short and long term objectives as well as complying guidelines and procedures in relation to WHS (Donald \& Canter, 1994).

\subsubsection{Incentives}

Incentives through rewards/punishments encourage employees to participate in the various WHS activities, which aim to get feedback as well as promote and build a safety culture in the work environment (Eiff, 1999; Vredenburgh, 2002).

\subsubsection{Training and Development}

WHS continuous training enhance employees' abilities, competencies, skills, and aptitude in terms of risk identification, assessment, and control (O'Toole, 2002; Silva, Lima, \& Baptista, 2004; Vredenburgh, 2002).

\subsubsection{Communication}

Clear and effective communication of information with workforce in relation to previous and current WHS incidents in the workplace and how they can be controlled (DeJoy, Schaffer, Wilson, Vandenberg, \& Butts, 2004; Silva et al., 2004; Siu, Phillips, \& Leung, 2003).

\subsubsection{Planning}

Planning can be emergency and preventative. Emergency planning build systems and processes that help business and its workforce apply an educated prompt response to risks, while preventative planning build systems and processes that help business and its workforce prevent risks and ultimately avoid incidents (Guldenmund, 2000; O'Toole, 2002).

\subsubsection{Control}

Control is developing processes and procedures that suite the specific workplace environment, comply with specific government and industry safety standards, and aim to reduce or potentially eliminate risks (Grote \& Künzler, 2000; Vredenburgh, 2002). Control is executed internally (Kjellen, Boe, \& Hagen, 1997) by analysing working conditions 
and events occurring within the business and externally through benchmarking techniques (Fuller, 1999) that compares with other business' safety records.

\section{Method}

This pilot study uses descriptive statistics. A self-completion questionnaire measuring instrument is used to examine small construction business owners' understanding and commitment to the implementation of work health and safety (WHS). A thirty four items from (Muniz et al., 2009) are used to measure the six dimensions of WHS: safety policy (4 items), employee incentives (5), training (9), communication (4), planning (7), and control (5). Factor analysis has been used to confirm the dimensions of the construct that has been operationalized, and to indicate which of the items are most appropriate for each dimension, thus establishing construct validity. All items are measured on a 5 point Likert-type interval scale ranging from " $1=$ strongly disagree" to " $5=$ strongly agree". The measures are reported by their developers to have convergent and discriminant validity.

\subsection{Sample Design}

This pilot study attempts to obtain preliminary information in a quick way and not to produce findings that are generalizable to the population, therefore a judgment purposive sampling design is used to obtain information from a specific target group, small construction business owners, who are the best to provide the information required. A self-completion questionnaire is emailed to ten small construction business owners obtained from the researcher's list of contacts. The ten businesses are based in the State of New South Wales, which preserves the necessary homogeneity in terms of legal context and WHS regulations largely determined by the state government.

\section{Results and Discussion}

Tables 1 to 7 show the survey responses collected from the business owners in relation to each dimension, while Table 8 show the complete survey responses collected from the business owners.

Table 1. Policy

\begin{tabular}{lccc}
\hline & Value & Frequency & Percent \\
\hline Undecided & 3 & 1 & 10 \\
Agree & 4 & 5 & 50 \\
strongly agree & 5 & 4 & 40 \\
\hline
\end{tabular}

Table 1 shows that five respondents agree and four respondents strongly agree that they have a safety policy that contains commitment to continuous improvement and to the well-being of their workers, and outlines safety responsibilities, while one respondent undecided. Therefore, $90 \%$ of respondents at least agree that they have a safety policy.

Table 2. Incentive/Participate

\begin{tabular}{lccc}
\hline & Value & Frequency & Percent \\
\hline Undecided & 3 & 1 & 10 \\
Agree & 4 & 6 & 60 \\
Strongly agree & 5 & 3 & 30 \\
\hline
\end{tabular}

Table 2 shows that six respondents agree and three respondents strongly agree that they always encourage their employees to participate in resolving and implementing safety issues and are rewarded when doing so, while one respondent undecided. Therefore, $90 \%$ of respondents at least agree that they have an incentive system.

Table 3.Training

\begin{tabular}{lccc}
\hline & Value & Frequency & Percent \\
\hline Disagree & 2 & 1 & 10 \\
Undecided & 3 & 1 & 10 \\
Agree & 4 & 5 & 50 \\
Strongly agree & 5 & 3 & 30 \\
\hline
\end{tabular}


Table 3 shows that five respondents agree and three strongly agree that their employees are provided with on-going and sufficient safety training during working hours and supply them with supporting documents, while one respondent disagree and one undecided. Therefore, $80 \%$ of respondents at least agree that they have a training system.

Table 4. Communication

\begin{tabular}{llll}
\hline & Value & Frequency & Percent \\
\hline Disagree & 2 & 3 & 30 \\
Undecided & 3 & 1 & 10 \\
Agree & 4 & 4 & 40 \\
Strongly agree & 5 & 2 & 20 \\
\hline
\end{tabular}

Table 4 shows that four respondents agree and two respondents strongly agree that their employees engage in regular in house and on site safety meetings to discuss work related risks and are provided with documentations that explain safety information and procedures, while three disagree and one undecided. Therefore, $60 \%$ of respondents at least agree that they have a communication system.

Table 5. Preventative planning

\begin{tabular}{lccc}
\hline & Value & Frequency & Percent \\
\hline Disagree & 2 & 1 & 10 \\
Undecided & 3 & 2 & 20 \\
Agree & 4 & 5 & 50 \\
Strongly agree & 5 & 2 & 20 \\
\hline
\end{tabular}

Table 5 shows that five respondents agree and two strongly agree that the company has a safety system that allows for the identification, evaluation and prevention of risks and gets reviewed regularly, while one respondent disagree and two undecided. Therefore, $70 \%$ of respondents at least agree that they have preventative planning.

Table 6. Emergency Planning

\begin{tabular}{lccc}
\hline & Value & Frequency & Percent \\
\hline Disagree & 2 & 1 & 10 \\
Undecided & 3 & 3 & 30 \\
Agree & 4 & 4 & 40 \\
Strongly agree & 5 & 2 & 20 \\
\hline
\end{tabular}

Table 6 shows that four respondents agree and two strongly agree that their employees are informed of the company's emergency plan to prevent serious risks, while one respondent disagrees and three undecided. Therefore, $60 \%$ of respondents at least agree that they have emergency planning.

Table 7. Control

\begin{tabular}{lccc}
\hline & Value & Frequency & Percent \\
\hline Disagree & 2 & 2 & 20 \\
Undecided & 3 & 3 & 30 \\
Agree & 4 & 4 & 40 \\
Strongly agree & 5 & 1 & 10 \\
\hline
\end{tabular}

Table 7 shows that four respondents agree and one strongly agree that their business develop processes and procedures that suite the specific workplace environment, comply with specific government and industry safety 
standards, and aim to reduce or potentially eliminate risks. Two respondents disagree and three undecided. Therefore, $50 \%$ of respondents at least agree that they have a control system.

Table 8. Complete survey responses

\begin{tabular}{|c|c|c|c|c|c|c|c|}
\hline & Policy & Incentive & Training & Communication & $\begin{array}{c}\text { Preventative } \\
\text { Planning }\end{array}$ & $\begin{array}{c}\text { Emergency } \\
\text { Planning }\end{array}$ & Control \\
\hline Company 1 & $\begin{array}{c}\text { Agree } \\
\text { Strongly }\end{array}$ & Undecided & Disagree & Disagree & Agree & Agree & Disagree \\
\hline Company 2 & $\begin{array}{l}\text { Agree } \\
\text { Strongly }\end{array}$ & $\begin{array}{l}\text { Agree } \\
\text { Strongly }\end{array}$ & $\begin{array}{c}\text { Agree } \\
\text { Strongly }\end{array}$ & Agree & Agree & Agree & Undecided \\
\hline Company 3 & Agree & Agree & Agree & Agree & Agree & Agree & Agree \\
\hline Company 4 & Undecided & Agree & Agree & Disagree & Undecided & Undecided & Disagree \\
\hline Company 5 & $\begin{array}{l}\text { Agree } \\
\text { Strongly }\end{array}$ & $\begin{array}{l}\text { Agree } \\
\text { Strongly }\end{array}$ & $\begin{array}{l}\text { Agree } \\
\text { Strongly }\end{array}$ & Agree & $\begin{array}{c}\text { Agree } \\
\text { Strongly }\end{array}$ & $\begin{array}{c}\text { Undecided } \\
\text { Strongly }\end{array}$ & $\begin{array}{l}\text { Agree } \\
\text { Strongly }\end{array}$ \\
\hline Company 6 & Agree & Agree & Agree & Strongly Agree & Agree & Agree & Agree \\
\hline Company 7 & Agree & Agree & Undecided & Disagree & Disagree & Disagree & Agree \\
\hline Company 8 & $\begin{array}{l}\text { Agree } \\
\text { Strongly }\end{array}$ & $\begin{array}{l}\text { Agree } \\
\text { Strongly }\end{array}$ & $\begin{array}{c}\text { Agree } \\
\text { Strongly }\end{array}$ & Agree & $\begin{array}{c}\text { Agree } \\
\text { Strongly }\end{array}$ & $\begin{array}{c}\text { Agree } \\
\text { Strongly }\end{array}$ & Agree \\
\hline Company 9 & Agree & Agree & Agree & Strongly Agree & Agree & Agree & Undecided \\
\hline Company 10 & Agree & Agree & Undecided & Undecided & Undecided & Undecided & Undecided \\
\hline
\end{tabular}

Table 8 shows that small business owners take a positive approach to implementing WHS. Companies 3, 6, 8 implement the seven dimensions of WHS, while companies 2 and 9 implement six of the seven dimensions of WHS. Three companies 1, 4, and 7 show disagreement with implementing two to three dimensions of the seven dimensions. Seven companies are undecided about implementing one dimension or more of the seven dimensions of WHS.

This positive approach toward WHS is in line with (Hasle et al., 2011) who conclude that owner managers of small business in the construction industry take a positive approach to their WHS environment. It is also in line with a study by Vickers, James, Smallbone, \& Baldocket (2005) who find that small business in the construction industry possesses high awareness of WHS compared to other industries.

Therefore, these findings explain the recent data published by SWA (2016), which show that the Australian average incident rate for the construction industry has decreased by $11 \%$ between 2011-12 and 2014-15 and worker fatalities is down by $19 \%$ compared to worker fatalities in the construction industry in the previous ten years.

\section{Conclusion and Limitations}

The findings of this study show that small business owners in the construction industry take a positive approach to implementing WHS, which confirm small business contribution to the recent reduction in incident rate and fatalities in the Construction industry.

Some limitations of the research need to be acknowledged. The findings presented may not be generalised to a wider population of small construction businesses in Australia due to the small sample surveyed. However, the findings represent a snapshot of the reality of small construction business owners' commitment to WHS in Australia. The use of quantitative research usually requires a large number of cases representing the population of interest in order to determine the statistical significance of results, therefore further research with larger samples is required to confirm the findings of this study.

\section{References}

Australia Parliament House. (2015). Statistical snapshot: small business contribution to economic performance in Australia. https://www.aph.gov.au/About_Parliament/Parliamentary_Departments/Parliamentary_Library/pubs/rp/rp1516/ Perform

Australia Parliament House. (2016). Statistical snapshot: count of small businesses. Retrieved from https://www.aph.gov.au/About_Parliament/Parliamentary_Departments/Parliamentary_Library/pubs/rp/rp1516/ Count 
Australian Bureau of Statistics. (2017). Counts of Australian Businesses, including Entries and Exits, Jun 2012 to Ju 2016.

Retrieved

from http://www.abs.gov.au/ausstats/abs@.nsf/Lookup/8165.0main+features1Jun\%202012\%20to\%20Jun\%202016

Cohen, A. (1977). Factors in successful occupational safety programs. Journal of Safety Research, 9(4), 168-178.

DeJoy, D.M., Schaffer, B.S., Wilson, M.G., Vandenberg, R.J., \& Butts, M.M. (2004). Creating safer workplaces: assessing the determinants and role of safety climate. Journal of Safety Research, 35, 81-90. https://doi.org/10.1016/j.jsr.2003.09.018

Donald, I., \& Canter, D. (1994). Employee attitudes and safety in the chemical industry. Journal of Loss Prevention in the Process Industries, 7, 203-208. https://doi.org/10.1016/0950-4230(94)80067-7

Eiff, G. (1999). Organizational safety culture. In Proceedings of the Tenth International Symposium on Aviation Psychology (pp. 1-14). Columbus. Libro de Actas.

Fuller, C.W. (1999). An employee management consensus approach to continuous improvement in safety management. Employee Relations, 21, 405-417. https://doi.org/10.1108/01425459910285528

Grote, G., \& Künzler, C. (2000). Diagnosis of safety culture in safety management audits. Safety Science 34, 131-150. https://doi.org/10.1016/S0925-7535(00)00010-2

Guldenmund, F.W. (2000). The nature of safety culture: a review of theory and research. Safety Science, 34, 215-257. https://doi.org/10.1016/S0925-7535(00)00014-X

Hasle, P., Limborg, H., Kallehave, T., Klitgaard, C., \& Andersen, T. (2011). The working environment in small firms: Responses from owner-managers. International Small Business Journal, 30(6), 622-639. https://doi.org/10.1177/0266242610391323

Holmes, N., Lingard, H., Yesilyurt, Z., \& DeMunk, F. (1999). An exploratory study of meanings of risk control for long term and acute effect occupational health and safety risks in small business construction firms. Journal of Safety Research, 30, 251-261. https://doi.org/10.1016/S0022-4375(99)00020-1

Kjellen, U., Boe, K., \& Hagen, L. (1997). Economic effects of implementing internal control of health, safety and environment: A retrospective case study of an aluminium plant. Safety Science 27, 99-114. https://doi.org/10.1016/S0925-7535(97)00066-0

Koper, B, Moller, K., \& Zwetsloot, G. (2009). The occupational safety and health scorecard - A business case example for strategic management. Scandinavian Journal of Work, Environment \& Health, 35(6), 413-420. https://doi.org/10.5271/sjweh.1361

Lingard, H., \& Holmes, N. (2001). Understandings of occupational health and safety risk control in small business construction firms: barriers to implementing technological controls. Construction Management and Economics, 19, 217-226. https://doi.org/10.1080/01446190010002570

McVittie, D., Banikin, H., \& Brocklebank, W. (1997). The effect of firm size on injury frequency in construction. Safety Science, 27, 19-23. https://doi.org/10.1016/S0925-7535(97)00048-9

Muniz, B., Peon, J., \& Vazquez-Ordas, C. (2009). Relation between occupational safety management and firm performance. Safety Science, 47, 980-991. https://doi.org/10.1016/j.ssci.2008.10.022

O'Toole, M.F. (2002). The relationship between employees' perceptions of safety and organizational culture. Journal of Safety Research, 33, 231-243. https://doi.org/10.1016/S0022-4375(02)00014-2

Safe Work Australia. (2015). Work Health and Safety Perceptions: Construction Industry. Retrieved from https://www.safeworkaustralia.gov.au/system/files/documents/1702/whs-perceptions construction-industry.pdf

Safe Work Australia. (2016). Work-related Traumatic injury Fatalities, Australia. Retrieved from https://www.safeworkaustralia.gov.au/system/files/documents/1710/work-related-traumatic-injury-fatalities-re port-2016.pdf

Silva, S., Lima, M.L., Baptista, C. (2004). OSCI: an organizational and safety climate inventory. Safety Science, 42, 205-220. https://doi.org/10.1016/S0925-7535(03)00043-2

Siu, O.L., Phillips, D., \& Leung, T.W. (2003). Age differences in safety attitudes and safety performance in Hong Kong construction workers. Journal of Safety Research, 34, 199-205. https://doi.org/10.1016/S0022-4375(02)00072-5 
Smallman, C. (2001). The reality of revitalizing health and safety. Journal of Safety Research, 32, 391-439. https://doi.org/10.1016/S0022-4375(01)00065-2

Vickers, I., James, P., Smallbone, D., \& Baldock, R. (2005). Understanding small firm responses to regulation: the case of workplace health and safety. Policy studies, 26(2), 149-169. https://doi.org/10.1080/01442870500127626

Vredenburgh, A. (2002). Organizational safety: which management practices are most effective in reducing employee injury rates?. Journal of Safety Research, 33, 259-276. https://doi.org/10.1016/S0022-4375(02)00016-6

Zohar, D. (1980). Safety climate in industrial organizations: theoretical and applied implications. Journal of Applied Psychology, 65(1), 96. https://doi.org/10.1037/0021-9010.65.1.96 